\title{
Purification, characterization and immunogenicity assessment of glutaminase free L-asparaginase from Streptomyces brollosae NEAE-115
}

Noura El-Ahmady El-Naggar ${ }^{1 *}$ (D, Sahar F. Deraz ${ }^{2}$, Sara M. El-Ewasy ${ }^{1}$ and Ghada M. Suddek ${ }^{3}$

\begin{abstract}
Background: L-asparaginase is a potential therapeutic enzyme widely used in the chemotherapy protocols of pediatric and adult patients with acute lymphoblastic leukemia. However, its use has been limited by a high rate of hypersensitivity in the long-term used. Hence, there is a continuing need to search for other L-asparaginase sources capable of producing an enzyme with less adverse effects.

Methods: Production of extracellular L-asparaginase by Streptomyces brollosae NEAE-115 was carried out using submerged fermentation. L-asparaginase was purified by ammonium sulphate precipitation and pure enzyme was reached using ion-exchange chromatography, followed by enzyme characterization. Anticancer activity towards Ehrlich Ascites Carcinoma (EAC) cells was investigated in female Swiss albino mice by determination of tumor size and the degree of tumor growth inhibition. The levels of anti-L-asparaginase $\lg G$ antibodies in mice sera were measured using ELISA method.

Results: The purified L-asparaginase showed a total activity of 795.152 with specific activity of $76.671 \mathrm{U} / \mathrm{mg}$ protein and 7.835 - purification fold. The enzyme purity was confirmed by using SDS-PAGE separation which revealed only one distinctive band with a molecular weight of $67 \mathrm{KDa}$. The enzyme showed maximum activity at $\mathrm{pH} 8.5$, optimum temperature of $37^{\circ} \mathrm{C}$, incubation time of $50 \mathrm{~min}$ and optimum substrate concentration of $7 \mathrm{mM}$. A Michaelis-Menten constant analysis showed a $\mathrm{K}_{\mathrm{m}}$ value of $2.139 \times 10^{-3} \mathrm{M}$ with L-asparagine as substrate and $V_{\max }$ of $152.6 \mathrm{UmL}^{-1} \mathrm{~min}^{-1}$. The half-life time $\left(\mathrm{T}_{1 / 2}\right)$ was $65.02 \mathrm{~min}$ at $50^{\circ} \mathrm{C}$, while being $62.65 \mathrm{~min}$ at $60^{\circ} \mathrm{C}$. Furthermore, mice treated with Streptomyces brollosae NEAE-115 L-asparaginase showed higher cytotoxic effect (79\% tumor growth inhibition) when compared to commercial L-asparaginase group (67\% tumor growth inhibition).
\end{abstract}

Conclusions: The study reveals the excellent property of this enzyme which makes it highly valuable for development of chemotherapeutic drug.

Keywords: Streptomyces brollosae NEAE-115, L-asparaginase, Purification, DEAE Sepharose CL-6B, Characterization, Immunogenicity assessment

\footnotetext{
* Correspondence: nouraelahmady@yahoo.com

'Department of Bioprocess Development, Genetic Engineering and

Biotechnology Research Institute, City of Scientific Research and

Technological Applications, Alexandria, Egypt

Full list of author information is available at the end of the article
}

(c) The Author(s). 2018 Open Access This article is distributed under the terms of the Creative Commons Attribution 4.0 International License (http://creativecommons.org/licenses/by/4.0/), which permits unrestricted use, distribution, and reproduction in any medium, provided you give appropriate credit to the original author(s) and the source, provide a link to the Creative Commons license, and indicate if changes were made. The Creative Commons Public Domain Dedication waiver (http://creativecommons.org/publicdomain/zero/1.0/) applies to the data made available in this article, unless otherwise stated. 


\section{Background}

$\mathrm{L}$-asparaginase (EC 3.5.1.1) is the enzyme that catalyzes the hydrolysis of L-asparagine to L-aspartic acid and ammonia. The leukemic cells cannot synthesize L-asparagine due the absence of L-asparagine synthetase [1]. "These cells require huge amount of L-asparagine and rely on the exogenous sources for their proliferation and survival. Thus, intravenously injection of L-asparaginase in cancer patients destroys the exogenous L-asparagine and results in depletion of L-asparagine in the blood. L-asparagine starvation affecting selectively the tumor cells, since they are unable to complete protein synthesis [2]". On the contrary, normal cells are protected from L-asparagine starvation due to their ability to synthesize this amino acid which is essential for both cell survival and protein synthesis [3]. Hence, in combination therapy of children acute lymphoblastic leukemia (ALL), L-asparaginase is considered as the effective drug of choice $[4,5]$. In addition, L-asparaginase is significantly used for the treatment of other malignant disorders including lymphosarcoma, acute lymphoblastic leukemia, chronic lymphocytic leukemia, acute myelomonocytic leukemia, acute myelocytic leukemia, Hodgkin disease, melanosarcoma and reticulosarcoma [6].

Currently, two formulations of L-asparaginases are effectively in clinical use for ALL treatments, one from Erwinia chrysanthemi and the other from E. coli. However, its therapeutic long-term use leads to unpleasant side effects as a result of exerting normal cells toxicity, patient's hypersensitivity and the rapid clearance of the enzyme from the blood stream which limited its administration. Clinical uses indicate that the $\mathrm{L}$-asparaginases toxicity is mainly resulted from enzyme glutaminase activity and bacterial endotoxins in enzyme preparations [7]. Hepatotoxicity is the important adverse effect in the majority of patients [8], L-asparaginase causes a wide spectrum of side effects, such as skin rashes, fever, hepatic dysfunction, leucopoenia, pancreatitis, diabetes, neurological seizures and abnormal coagulation tests that may lead to intracranial thrombosis or haemorrhage [3]. L-asparaginase purification consider as an essential step for its physical and biological characterization. Moreover, for effective therapeutic administration with less adverse effects, L-asparaginase preparation must be free of any contaminants and impurities which also required efficient purification step.

In an attempt to minimize the allergenic reactions caused by impurities, enormous numbers of research groups have achieved production and purification of L-asparaginase [9]. Manivasagan et al. [10] reported that actinomycetes have been recognized to be a good source for L-asparaginase production, in particular Streptomyces species which are responsible for providing almost half of the useful drugs of bioactive secondary metabolites, especially antibiotics followed by enzymes and anti cancer agents. Several Streptomyces species have been explored for L-asparaginase production such as Streptomyces parvus NEAE-95 [11], Streptomyces olivaceus NEAE-119 [12] and Streptomyces gulbargensis [13]. The aim of the present work is the purification, characterization and immunogenicity assessment of an extracellular L-asparaginase produced under submerged fermentation from Streptomyces brollosae NEAE-115.

\section{Methods}

\section{Microorganisms and cultural conditions}

Soil samples collected from different areas in Egypt "Mansoura city, Damietta city, north western coast of Egypt from New Borg El-Arab to El Saloum, Janaklis (Beheira) and Brollos Lake" and three soil samples collected from Taif in Saudi Arabia were used for the isolation of actinomycetes, mainly Streptomyces spp. Streptomyces brollosae NEAE-115 was isolated from soil sample collected from Brollos Lake at the Mediterranean coast of Egypt. Streptomyces spp. had been isolated from the soil using standard dilution plate method on starch nitrate agar medium containing the following constituents (g/L): Starch, 20; $\mathrm{CaCO}_{3}, 3 ; \mathrm{MgSO}_{4} .7 \mathrm{H}_{2} \mathrm{O}, 0.5$; $\mathrm{KNO}_{3}, 2 ; \mathrm{NaCl}, 0.5 ; \mathrm{K}_{2} \mathrm{HPO}_{4}, 1 ; \mathrm{FeSO}_{4} .7 \mathrm{H}_{2} \mathrm{O}, 0.01$; agar, 20. The incubation was carried at $30{ }^{\circ} \mathrm{C}$ for a period of 7 days. The obtained isolates of Streptomyces were purified and stored as spore suspensions in $20 \%(\mathrm{v} / \mathrm{v})$ glycerol at $-20{ }^{\circ} \mathrm{C}$ for subsequent investigation.

\section{Screening of L-asparaginase production by plate assay method}

According to De Jong [14], an increase in the culture filtrates $\mathrm{pH}$ is accompanied by L-asparaginase production. All actinomycetes isolates were tested for their abilities to produce $\mathrm{L}$-asparaginase using plates containing asparagine dextrose salts agar (ADS agar) medium [15]. The constituents of the ADS agar medium were (\%): L-asparagine 1.0; $\mathrm{K}_{2} \mathrm{HPO}_{4} \quad 0.1 ; \mathrm{MgSO}_{4}$ 0.05; dextrose 0.2; agar $1.5, \mathrm{pH}$ was adjusted to $6.8-7$. The medium was incorporated with $\mathrm{pH}$ indicator (phenol red, $0.009 \% \mathrm{w} / \mathrm{v}$ ) prepared in ethanol according to the procedure of Gulati et al. [16]. The actinomycetes isolates were inoculated on ADS agar plates and incubated at $30{ }^{\circ} \mathrm{C}$ for 7 days. The formation of a pink zone around the microbial colonies due to change of $\mathrm{pH}$ was considered as a positive result for L-asparaginase production. Two control plates were prepared one was uninoculated medium while the other was without dye. The more potent isolate exhibiting L-asparaginase activity was selected for further study.

\section{Inoculum preparation}

Three disks ( $8 \mathrm{~mm}$ each) were taken from old stock culture grown on starch nitrate agar medium for 7 days and inoculated into $50 \mathrm{~mL}$ of asparagine dextrose salts broth containing (\%): L-asparagine 1.0; $\mathrm{K}_{2} \mathrm{HPO}_{4} 0.1$; dextrose $0.2 ; \mathrm{MgSO}_{4}$ 0.05. The inoculated $250 \mathrm{~mL}$ 
Erlenmeyer flasks were grown at $30{ }^{\circ} \mathrm{C}$ and $150 \mathrm{rpm}$ for $48 \mathrm{~h}$ and cultured medium was further used for subsequent experiments.

Production of L-asparaginase by submerged fermentation The production of extracellular L-asparaginase from Streptomyces brollosae NEAE-115 was carried using the medium containing (g/L): Dextrose 2, starch 20, L-asparagine 10, $\mathrm{KNO}_{3} 1, \mathrm{~K}_{2} \mathrm{HPO}_{4} 1, \mathrm{MgSO}_{4} .7 \mathrm{H}_{2} \mathrm{O} 0.5, \mathrm{NaCl} 0.1, \mathrm{pH} 7$. Fifty $\mathrm{mL}$ of the broth medium was dispensed in $250 \mathrm{~mL}$ Erlenmeyer conical flask. The inoculated flasks (with inoculum size of $4 \%, v / v)$ were incubated on a rotary shaker incubator at $150 \mathrm{rpm}$ and $30^{\circ} \mathrm{C}$. After 7 days of incubation time, the broth was centrifuged with cooling centrifuge at $6000 \times g$ for $30 \mathrm{~min}$ at $4{ }^{\circ} \mathrm{C}$ and the clear supernatant served as crude enzyme.

\section{Assay of L-asparaginase activity}

Extracellular L-asparaginase activity was determined according to the method of Wriston and Yellin [17] using nesslerization to measure the amount of liberated ammonia. The reaction mixture containing $1.5 \mathrm{~mL}$ of $0.04 \mathrm{M} \mathrm{L}$-asparagine prepared in $0.05 \mathrm{M}$ Tris- $\mathrm{HCl}$ buffer, $\mathrm{pH} 8.6$ and $0.5 \mathrm{~mL}$ of the enzyme to make up the total volume to $2 \mathrm{~mL}$. The tubes were incubated at $37{ }^{\circ} \mathrm{C}$ for $30 \mathrm{~min}$. The reaction was terminated by the addition of $0.5 \mathrm{~mL}$ of $1.5 \mathrm{M}$ trichloroacetic acid (TCA). The blank was run by adding TCA followed by enzyme preparation. To remove the precipitated protein, the reaction contents were centrifuged at $10,000 \times g$ for $5 \mathrm{~min}$ and the filtrate was collected. For quantification of liberated ammonia, $0.5 \mathrm{~mL}$ filtrate was diluted to $7 \mathrm{~mL}$ with distilled water and $1 \mathrm{~mL}$ Nessler's reagent was added to the resulting mixture. The color reaction was allowed to proceed for $20 \mathrm{~min}$ before measuring the absorbance at $480 \mathrm{~nm}$ using Optizen Pop -UV/Vis spectrophotometer. A coloration of yellow indicates the presence of ammonia. However, a brown precipitate is formed at higher concentrations. The amount of liberated ammonia by the test sample was calculated by comparing the absorbance with a standard curve prepared from solutions of ammonium chloride as the ammonia source. One unit (U) of L-asparaginase is the amount of enzyme which generates $1 \mu$ mole of ammonia in $1 \mathrm{~min}$ at $37^{\circ} \mathrm{C}$ and $\mathrm{pH}$ 8.6.

\section{Assay of L-glutaminase}

L-glutaminase activity was determined using L-glutamine as substrate according to Imada et al. [18] method and the released ammonia was measured by using Nesseler's reagent.

\section{Purification of L-asparaginase from Streptomyces brollosae NEAE-115}

The crude enzyme extract used in L-asparaginase purification was obtained from production medium centrifuged at $6000 \times g$ for $30 \mathrm{~min}$ and the resulted supernatant was transferred into a conical flask placed in ice cold condition with stirring. Finely powdered ammonium sulfate was added until complete dissolving takes place to give $45 \%$ saturation with ammonium sulphate and kept overnight in the refrigerator at $4{ }^{\circ} \mathrm{C}$. The precipitate was collected by centrifugation at $11000 \times \mathrm{g}$ for $30 \mathrm{~min}$, while the supernatant was brought to $55-85 \%$ saturation with ammonium sulphate. Then, the formed precipitates were separately collected by centrifugation and dissolved in $50 \mathrm{mM}$ Tris- $\mathrm{HCl}$ buffer $\mathrm{pH}$ 8.4. The dialysis of the ammonium sulphate was carried out in a pre-treated dialysis tube. Precipitate formed during dialysis was removed by centrifugation and was discarded. For the present study dialysis tubing (SERVA pro, 44,144, diameter $21 \mathrm{~mm} \times$ $5 \mathrm{~m}$ ) was used. After dialysis, the samples were used for protein estimation by the method of Lowry et al. [19] and enzyme was assayed by the direct nesslerization method according to the method of Wriston and Yellin [17] and stored at $-20{ }^{\circ} \mathrm{C}$ for further purification. The concentrated enzyme solution was applied to the ion exchange column of DEAE-Sepharose CL-6B $(2.7 \times 20 \mathrm{~cm})$ that was pre-equilibrated with $50 \mathrm{mM}$ Tris- $\mathrm{HCl}$ buffer $(\mathrm{pH} 8.4)$. It was eluted with the same buffer containing increased concentration $(0.1-0.5 \mathrm{M})$ of $\mathrm{NaCl}$ solution to elute the enzyme at a flow rate of $10 \mathrm{~mL}$ per $1 \mathrm{~h}$. Fractions of $2 \mathrm{~mL}$ were collected, after fractions dialysis, the samples were subjected to protein estimation [19] and assay of L-asparginase activity [17]. Fractions showing high L-asparaginase activity were collected for further use.

\section{Physicochemical characterization of the purified enzyme}

The optimum $\mathrm{pH}$ of the purified enzyme was studied over the $\mathrm{pH}$ range of 4.5 to 10.5 with L-asparagine as a substrate dissolved in different buffers of $0.05 \mathrm{M}$ : citric acid- $\mathrm{Na}_{2} \mathrm{HPO}_{4}$ (pH 4.5-7.5), Tris- $\mathrm{HCl}(\mathrm{pH} 8.5)$ and glycine- $\mathrm{NaOH}(\mathrm{pH} 9.5-$ 10.5). The influence of temperature on L-asparaginase activity was analysed by incubating the assay mixture over the temperature range of 25 to $60{ }^{\circ} \mathrm{C}$ in $0.05 \mathrm{M}$ Tris- $\mathrm{HCl}$ buffer under assay conditions. The optimum substrate concentration for the enzyme activity was determined by incubating the purified enzyme in the presence of different substrate concentration (1-10 mM). To evaluate the incubation time effect on L-asparginase activity, the reaction mixture was incubated for different times $(10,20,30,40,50,60,70$ and $80 \mathrm{~min})$. Along the characterization of the enzyme, activity was determined as reported earlier.

\section{Determination of the kinetic parameters $\mathrm{K}_{\mathrm{m}}$ and $\mathrm{V}_{\max }$}

The kinetic parameters, Michaelis-Menten constant $\left(\mathrm{K}_{\mathrm{m}}\right)$ and maximal velocity $\left(\mathrm{V}_{\max }\right)$ of the purified L-asparaginase were determined with different concentrations of L-asparagine (1-10 $\mathrm{mM})$ as substrate and the data were fitted to a one-phase exponential 
association nonlinear regression curve using GraphPad Prism 5 software (GraphPad Software Inc., San Diego, CA). The enzyme activity was determined by measuring the rate of hydrolysis of L-asparagine under standard assay conditions using the Michaelis-Menten equation:

$$
\mathrm{V}_{0}=\frac{\mathrm{V}_{\max }[\mathrm{S}]}{\mathrm{K}_{\mathrm{m}}+[\mathrm{S}]}
$$

Whereas: initial reaction velocity $\left(\mathrm{V}_{0}\right)$, substrate concentration $[\mathrm{S}]$, the Michaelis-Menten constant $\left(\mathrm{K}_{\mathrm{m}}\right)$ and maximal velocity $\left(\mathrm{V}_{\text {max }}\right)$.

\section{Thermal stability of L-asparaginase}

The stability of the $\mathrm{L}$-asparaginase to temperature was determined by pre-incubating the reaction mixture (without its substrate) containing buffered enzyme for different time interval ( 0.0 to $90 \mathrm{~min}$ ) with different temperatures $\left(40,50,60,70\right.$ and $\left.80^{\circ} \mathrm{C}\right)$. After the end of the incubation periods, the enzyme was cooled and the residual activities were assayed.

\section{Estimation of deactivation rate constant $\left(\mathbf{k}_{\mathrm{d}}\right)$ and half-life time $\left(T_{1 / 2}\right)$}

The heat inactivation half-life $\left(\mathrm{T}_{1 / 2}\right)$ of the enzyme and thermal deactivation constant $\left(\mathrm{k}_{\mathrm{d}}\right)$ of the purified L-asparaginase produced by Streptomyces brollosae NEAE-115 were determined by using GraphPad Prism 5 software (GraphPad Software Inc., San Diego, CA). It was assumed that enzyme thermal deactivation is a reaction follows the first order kinetics (single step two-stage theory) [20] as follows:

$$
\mathrm{E} \rightarrow \mathrm{E}_{\mathrm{d}}
$$

Where, $\mathrm{E}$ is the active enzyme state and $\mathrm{E}_{\mathrm{d}}$ is the deactivated state. The first order deactivation can be represented as follows:

$$
\frac{\mathrm{dE}}{\mathrm{dt}}=-\mathrm{K}_{\mathrm{d}}[\mathrm{E}]
$$

Where, $K_{d}$ is the deactivation rate constant, $[\mathrm{E}]$ is concentration of the active enzyme.

Eq. (3) integrated with the initial condition, gives:

$$
\ln \left(\frac{E_{d}}{E}\right)=-K_{d} t
$$

This result is the exponential decay model. Therefore, by plotting $\log$ of $\left(E_{d} / E\right)$ against time, the deactivation rate constant value $\left(\mathrm{K}_{\mathrm{d}}\right)$ is obtained [21].

The half-life of the enzyme activity $\left(T_{1 / 2}\right)$ is the time it takes for the activity to reduce to a half of the initial activity value. The half-life time was determined by using the following equation:

$$
\mathrm{T}_{1 / 2}=\frac{\ln 2}{\mathrm{k}_{\mathrm{d}}}=\frac{0.693}{\mathrm{k}_{\mathrm{d}}}
$$

Where: $K_{d}$ is deactivation rate constant.

The deactivation rate constant $\left(\mathrm{K}_{\mathrm{d}}\right)$ at each temperature was determined from Arrhenius equation as:

$$
\ln \left(\frac{\mathrm{k}_{\mathrm{d}}}{\mathrm{k}_{0}}\right)=-\left(\frac{\mathrm{E}}{\mathrm{RT}}\right)
$$

Plotting the $\log$ of $\mathrm{K}_{\mathrm{d}}$ as a function of the inverse of the absolute temperature. The values of the deactivation energy (E) and $k_{0}$ (frequency factor, $\mathrm{min}^{-1}$ ) were obtained from the slope and intercept of the plot of $\ln \left(\mathrm{k}_{\mathrm{d}}\right)$ versus $(1 / T)$; respectively. $R$ is the universal gas constant and $\mathrm{T}$ is absolute temperature.

\section{Effect of $\mathrm{pH}$ on L-asparaginase stability}

To study the optimum $\mathrm{pH}$ for L-asparaginase stability, the enzyme in absence of its substrate was pre-incubated at room temperature for $0,6,12,18$, and $24 \mathrm{~h}$ in buffers of various $\mathrm{pH}$ values ( $\mathrm{pH} 4.5-10.5)$. The residual activity was assayed under the standard assay conditions.

\section{Effect of metal ions, inhibitors and surfactants on L- asparaginase activity}

The effects of various metal ions, inhibitors and surfactants on L-asparaginase activity were determined by preincubating the enzyme with individual metal ions solutions prior to adding the substrate at a final concentration of $5 \mathrm{mM}$ concentration and inhibitors and surfactants at $1 \mathrm{mM}$ concentration for $30 \mathrm{~min}[22]$ at $4{ }^{\circ} \mathrm{C}$. The residual activity of the enzyme was measured under the standard assay conditions. The relative activities were determined by considering 100\% activity of the enzyme without the addition of metal ions or inhibitors or surfactants as control.

\section{Molecular weight determination}

The purity degree and the mass of the purified L-asparaginase enzyme was determined by sodium dodecyl sulfate polyacrylamide gel electrophoresis (SDS-PAGE) according to the method of Laemmli [23] with a $10 \%$ separating acrylamide gel $(\mathrm{pH} 8.8)$ and a $5 \%$ stacking gel (pH 6.8) containing $0.1 \%$ SDS. Gels were stained with coomassie brilliant blue R-250 followed by distaining step with a mixture of methanol- acetic acid and water in the ratio of 4:1:5. Molecular weight of L-asparaginase was determined using standard molecular weight protein marker ranged from 9 to $178 \mathrm{kDa}$.

\section{Experimental animals}

Female Swiss albino mice with body weight of 20-30 g were received from Urology and Nephrology Center of Mansoura University, Mansoura, Egypt, used to compare the cytotoxic effect of L-asparaginase purified from 
Streptomyces brollosae NEAE-115 and those commercially available L-asparaginase from E. coli (Sigma-Aldrich, Product Number: A3809; CAS Number: 901568-3). Animals were housed in a conditioned atmosphere at temperature of $24 \pm 1{ }^{\circ} \mathrm{C}$ and $55 \pm 5 \%$ relative humidity with regular $12 \mathrm{~h}$ light/12 h dark cycles and free access to standard laboratory food and water. All experiments have been conducted under the regulations and the ethical guidelines for laboratory animals approved by the Ethical Committee of Faculty of Pharmacy, Mansoura University, Egypt.

\section{Transplantation of tumor}

Ehrlich ascites carcinoma cells (EAC) were supplied by the Netherlands Cancer Institute. The cells were maintained in vivo in female Swiss albino mice by serial intraperitoneal transplantation [24] in the laboratory of Faculty of Pharmacy, Mansoura University, Egypt.

\section{In vivo experiment and evaluation of antitumor activity}

The 7-10 days old EAC cells were used along experiment. Ascites fluid from tumor-bearing mice was withdrawn using a needle aspiration under aseptic conditions from the peritoneal cavity, and subjected to three times washing with normal saline followed by centrifugation at $67 \times g$. Tryphan blue exclusion test was used for tumor viability determination and haemocytometer was used for cells counting. To get ascitic fluid with a concentration of $5 \times 10^{5}$ viable EAC cells $/ 0.1 \mathrm{~mL}$ of tumor cell suspension normal saline was used and was injected into the right thigh of the lower limb of mice to obtain ascitic tumor [25].

The largest tumor diameter and its perpendicular were measured by a digital caliper and used for tumor growth determination [26].

$$
\text { Tumor size }\left(\mathrm{mm}^{3}\right)=0.5 \mathrm{Xa} \mathrm{Xb}^{2}
$$

Whereas: largest tumor diameter (a) and its perpendicular (b).

When the primary tumor reached a size of 50$100 \mathrm{~mm}^{3}$, Swiss albino mice were divided into three groups of six each. Group (1) received normal saline (EAC-bearing control, $5 \mathrm{~mL} / \mathrm{kg}$ ). Group (2) received commercial L-asparaginase. Group (3) received L-asparaginase produced by Streptomyces brollosae NEAE-115. L-asparaginase treatments were given five days after the inoculation, two times a week for two weeks. After $24 \mathrm{~h}$ of the last dose and then $18 \mathrm{~h}$ of fasting, animals of each group were sacrificed by cervical dislocation to determine the antitumor activity of the tested L-asparaginase. Antitumor activity was calculated by the determination of $\Delta \mathrm{T}$ (change of tumor size in the treatment group) and $\Delta C$ (change of tumor size in the control). The degree of tumor growth inhibition can be obtained from $\Delta \mathrm{T} / \Delta \mathrm{C}$ X 100 [26].

\section{Immunogenicity assessment}

Two groups each of 6 mice received intraperitoneal administration of either commercial L-asparaginase (250 U/ $\mathrm{kg}$ ) or Streptomyces brollosae NEAE-115 L-asparaginase $(250 \mathrm{U} / \mathrm{kg})$ twice a week for 4 weeks. Levels of specific antibodies (IgG immunoglobulin) against L-asparaginase or commercial product were measured in sera using ELISA method and microplate reader was used at absorbance of $450 \mathrm{~nm}$. The direct enzyme-linked immunosorbent assay (ELISA) was carried out to evaluate the presence of asparaginase-specific IgG antibodies in serum samples by employing horseradish peroxidase-conjugated goat-anti mouse IgG (from Southern Biotech). All ELISA steps were conducted at room temperature, and $2.5 \%$ casein $(\mathrm{w} / \mathrm{v})$ was utilized as binding and blocking buffer. The assay steps and conditions were as follows: $2 \mathrm{~h}$ blocking of asparaginase-coated plates followed by extensive washing using PBS-Tween, incubated with diluted serum samples for $2 \mathrm{~h}$, washed, incubated with detection antibody for $1 \mathrm{~h}$, washed, developed with 3, 3', 5, 5'-tetramethylbenzidine substrate for $30 \mathrm{~min}$, and quenched with $9.8 \%(\mathrm{v} / \mathrm{v})$ $\mathrm{H}_{2} \mathrm{SO}_{4}$ in water. IgG titers were calculated.

\section{Results}

Production of the L-asparaginase by Streptomyces brollosae NEAE-115 was detected by plate assay. The enzyme production was indicated by color change in the medium from yellow to pink zone surrounding the colony. A broad diameter of the pink zone around the colony indicated that the organism was an efficient producer of L-asparaginase. During shake flasks production of L-asparaginase, the mycelial growth has been formed as large, spherical pellets which may lead to better yield of L-asparaginase than growth as free filaments. The glutaminase activity of L-asparaginase was investigated and the enzyme is free from glutaminase activity.

\section{Purification of L-asparaginase from Streptomyces brollosae NEAE-115}

Purification of L-asparaginase of Streptomyces brollosae NEAE-115 was carried out using crude culture filtrate having a total activity of $30538.87 \mathrm{U}$, protein content $3120.42 \mathrm{mg}$ and specific activity of $9.786 \mathrm{U} / \mathrm{mg}$ protein. The dialysed ammonium sulphate concentrated enzyme had a specific activity of $69.004 \mathrm{U} / \mathrm{mg}$ protein with protein content of $158.86 \mathrm{mg}$ and the enzyme recovery was $35.895 \%$ with purification fold of 7.051 (Table 1). The dialyzed enzyme obtained after ammonium sulphate precipitation was used to purify the enzyme with DEAE Sepharose CL-6B packed column which resulting 260 fractions with major L-asparaginase peak on the 
Table 1 Summary of the purification steps of the L-asparaginase produced by Streptomyces brollosae NEAE-115

\begin{tabular}{|c|c|c|c|c|c|}
\hline \multirow[t]{2}{*}{ Purification step } & \multirow{2}{*}{$\begin{array}{l}\text { Total } \\
\text { protein } \\
\text { content (mg) }\end{array}$} & \multicolumn{2}{|c|}{ L-asparaginase activity } & \multirow{2}{*}{$\begin{array}{l}\text { Recovery } \\
\text { (\%) }\end{array}$} & \multirow{2}{*}{$\begin{array}{l}\text { Purification } \\
\text { fold }\end{array}$} \\
\hline & & Total activity $(U)$ & Specific activity (U/mg protein) & & \\
\hline Culture filtrate & 3120.42 & 30538.87 & 9.786 & 100 & 1 \\
\hline$\left(\mathrm{NH}_{4}\right)_{2} \mathrm{SO}_{4}$, post dialysis & 158.86 & 10,962 & 69.004 & 35.895 & 7.051 \\
\hline Ion exchange on DEAE Sepharose & 10.371 & 795.152 & 76.671 & 7.254 & 7.835 \\
\hline
\end{tabular}

chromatogram (Fig. 1). The final purification step, DEAE Sepharose CL-6B column, showed a total enzyme activity of 795.152, protein content of $10.371 \mathrm{mg}$ with enzyme specific activity of $76.671 \mathrm{U} / \mathrm{mg}$ of protein and the results of all purification steps applied to purify L-asparaginase produced by Streptomyces brollosae NEAE-115 are summarized in Table 1.

\section{SDS-PAGE and molecular weight determination}

The purity and molecular weight of the purified enzyme was determined by SDS-PAGE according to the method of Laemmli [23] with gel system contained a separating gel of $10 \%$ and a stacking gel $5 \%$. After the electrophoresis, protein bands were visualized by staining with coomassie brilliant blue R-250. The resolved electrophoretic bands of the enzyme from different purification steps on the SDS-PAGE showed that the enzyme purity was successfully improved. SDS-PAGE separation of the enzyme preparation showed no detectable contamination and electrophoretic resolved only one distinctive band. By using different molecular markers with known molecular weight ranged from 9 to $178 \mathrm{kDa}$, the molecular mass of the purified L-asparaginase was estimated. The relative mobility $\left(R_{f}\right)$ value was calculated for the distinctive single band. The calculated $R_{f}$ value is compared with the different standard proteins of known molecular weight. Hence the molecular weight for individual band is determined with a molecular mass of $67 \mathrm{kDa}$ (Fig. 2).

Physicochemical properties of the purified L-asparaginase The purified L-asparginase of Streptomyces brollosae NEAE-115 was characterized for its activity at different $\mathrm{pH}$ levels, temperatures, substrate concentrations and incubation times.

\section{Effect of pH on L-asparaginase activity}

The $\mathrm{pH}$ of the reaction played a vital role in most of enzymatic processes. There are number of reports on the enzyme activity at near physiological range. Fig. 3 shows that the purified L-asparaginase was active over a broad $\mathrm{pH}$ range of 4.5 to 10.5 with an optimum of $48.462 \mathrm{U} /$ $\mathrm{mL}$ at $\mathrm{pH}$ 8.5. At higher pH's, the enzyme activity was decreased. The enzyme retains $71.595 \%$ activity even at $\mathrm{pH} 10.5$ and $58.919 \%$ at $\mathrm{pH} 5.5$.

\section{Incubation time effect on enzyme activity}

L-asparaginase activity of Streptomyces brollosae NEAE-115 (Fig. 4) was gradually increased with increasing incubation time up to $50 \mathrm{~min}$ (L-asparaginase activity of $71.327 \mathrm{U} /$ $\mathrm{mL})$. After which only a slight decrease in L-asparaginase activity was observed.

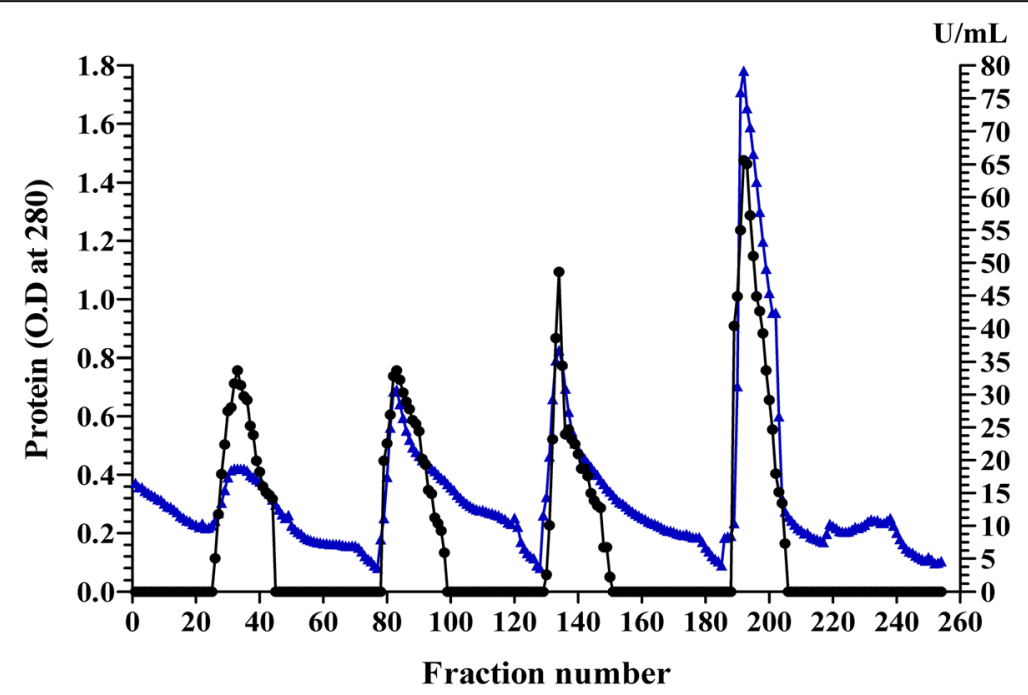

Fig. 1 Purification of L-asparaginase produced by Streptomyces brollosae NEAE-115 using ion exchange on DEAE Sepharose. ( $\mathbf{\Lambda}$ ) refer to protein, (•) refer to L-asparaginase activity 


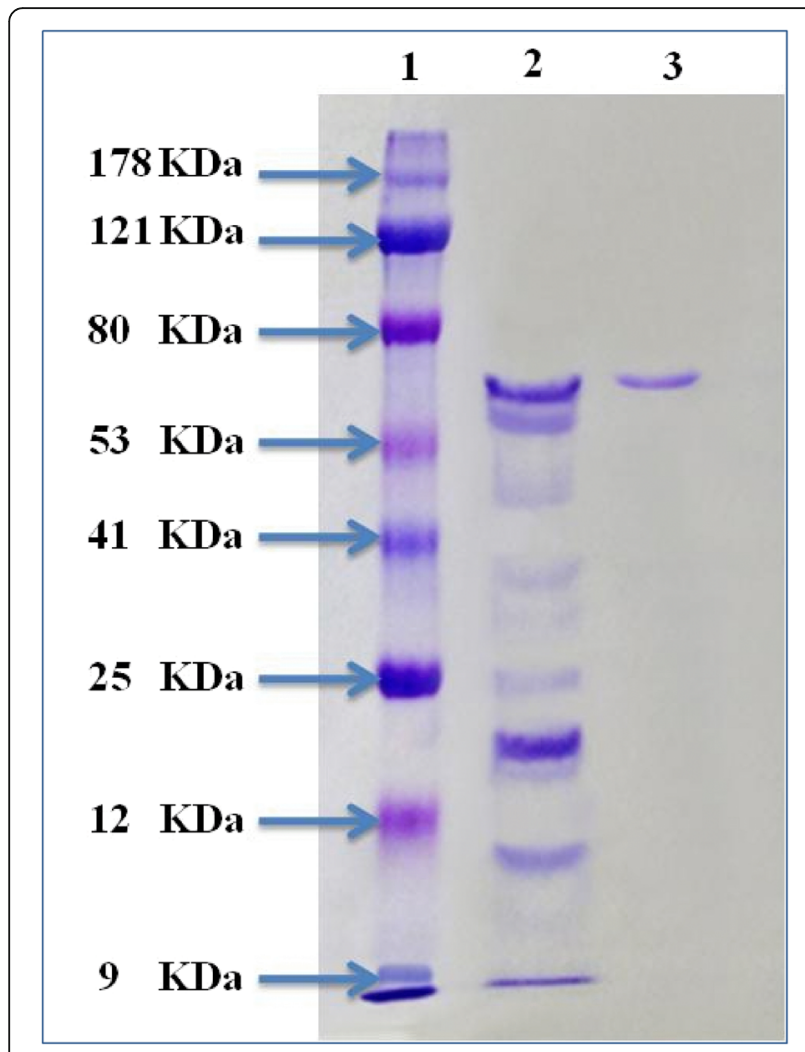

Fig. 2 SDS-polyacrylamide gel electrophoresis of the purified Lasparaginase from Streptomyces brollosae NEAE-115. Lane 1: Protein marker; Lane 2: Ammonium sulphate fraction; Lane 3: Purified protein

Temperature effect on L-asparaginase activity

Figure 5 shows that the purified L-asparaginase was active over a wide range of temperature range of 25 to $60{ }^{\circ} \mathrm{C}$ with an optimum L-asparaginase activity of $87.81 \mathrm{U} / \mathrm{mL}$ at $37{ }^{\circ} \mathrm{C}$ and lower L-asparaginase activity observed at higher temperatures.

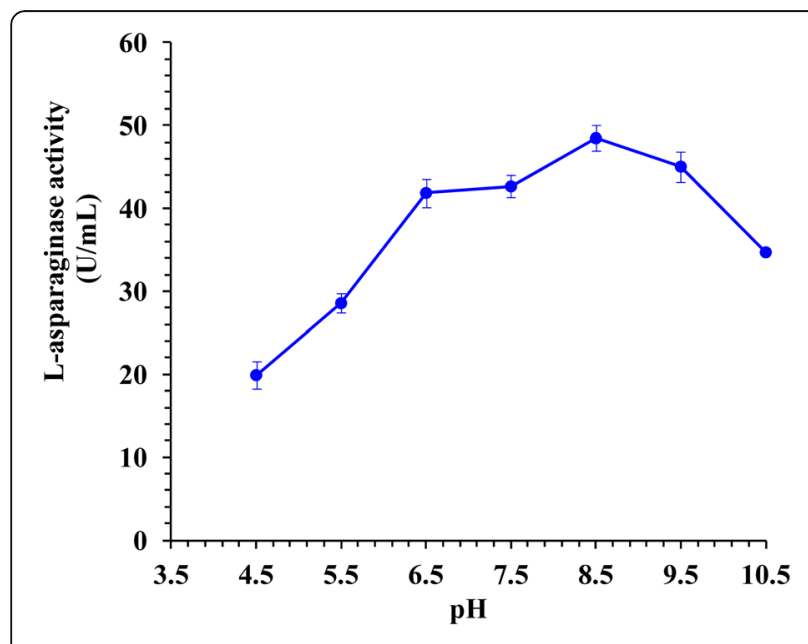

Fig. 3 Activity of L-asparaginase as a function of the $\mathrm{pH}$ of the reaction

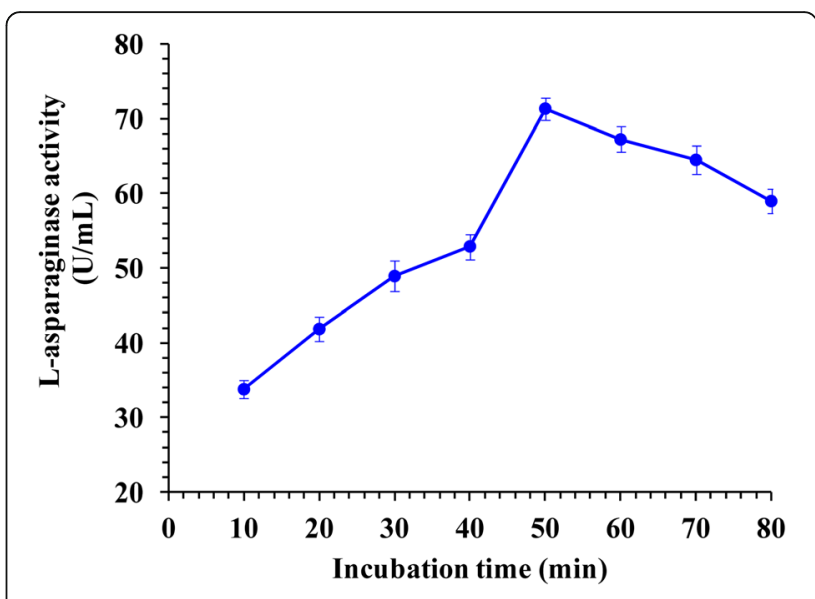

Fig. 4 Effect of different incubation time on L-asparaginase activity

\section{Effect of substrate concentration on the activity of L-} asparaginase

The results in Fig. 6 showed the effect of various substrate concentrations ranging from 1 to $10 \mathrm{mM}$ on the activity of L-asparaginase and verified the optimum required substrate concentration that gives the maximum L-asparaginase activity. The obtained results illustrated a gradual enzyme activity increase with increasing of the substrate concentration up to $7 \mathrm{mM}$ demonstrating the optimum substrate concentration for enzyme activity. However, higher substrate concentration (8 to $10 \mathrm{mM}$ ) resulted in decreasing of enzyme activity. Activation of asparagine hydrolysis was investigated in terms of change in values of kinetic constants $\left(\mathrm{K}_{\mathrm{m}}\right.$ and $\left.\mathrm{V}_{\max }\right)$. The $\mathrm{K}_{\mathrm{m}}$ and $\mathrm{V}_{\max }$ values were calculated through Michaelis-Menten plot by plotting the relation between different substrate concentrations $[\mathrm{S}]$ versus enzyme activity (V), using enzyme kinetic template of Graph-Pad Prism 4 software. Michaelis-Menten plot showed in Fig. 7 illustrated the $\mathrm{K}_{\mathrm{m}}$ and $\mathrm{V}_{\max }$ values for $\mathrm{L}$-asparaginase

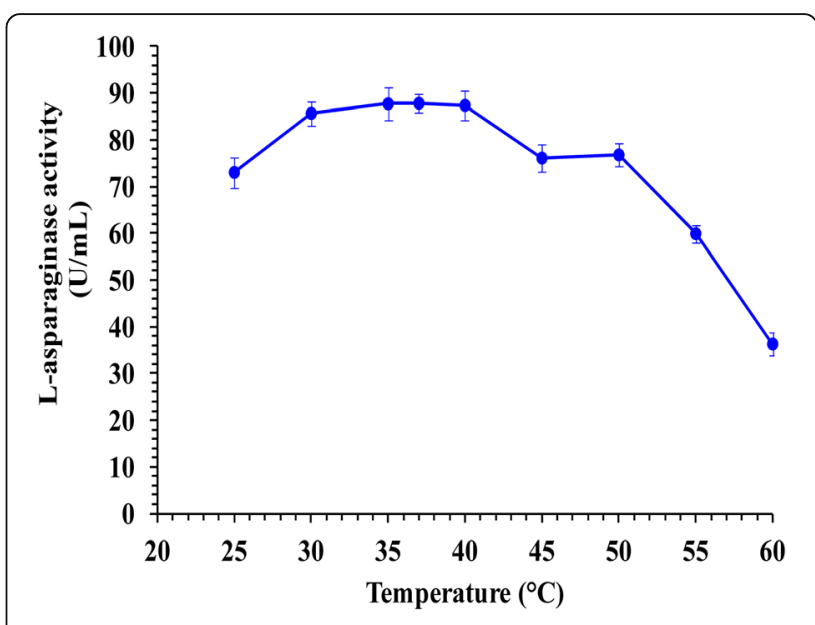

Fig. 5 Effect of the temperature on L-asparaginase activity 


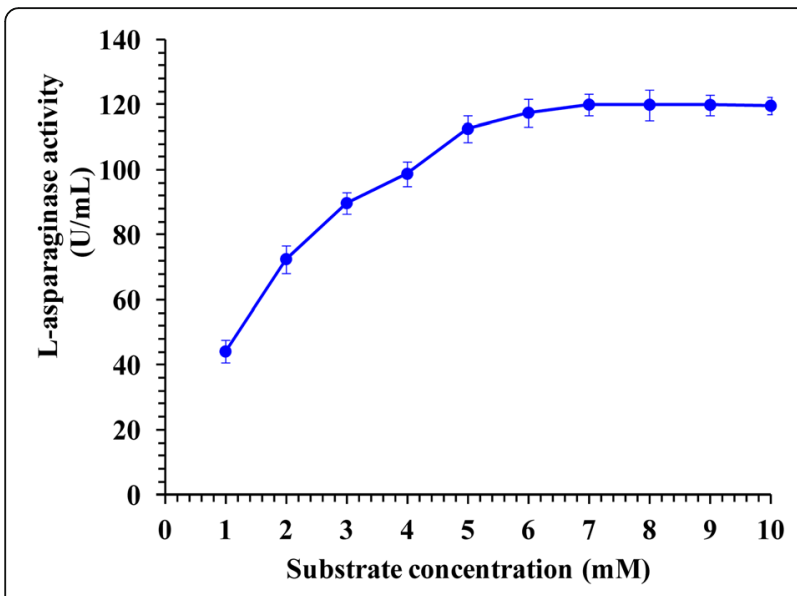

Fig. 6 Effect of the substrate concentration of the reaction on L-asparaginase activity

enzyme. The plot gave $K_{m}$ value of $2.139 \times 10^{-3} \mathrm{M}$ and $\mathrm{V}_{\max }$ of $152.6 \mathrm{UmL}^{-1} \mathrm{~min}^{-1}$ for the hydrolysis of L-asparagine by L-asparaginase from Streptomyces brollosae NEAE-115 and $\mathrm{K}_{\mathrm{m}}$ value of $1.76 \times 10^{-4} \mathrm{M}$ and $\mathrm{V}_{\max }$ of $121.7 \mathrm{UmL}^{-1} \mathrm{~min}^{-1}$ for the hydrolysis of L-asparagine by commercially available L-asparaginase from E. coli (Sigma-Aldrich, Product Number: A3809; CAS Number: 9015-68-3).

\section{Thermal stability}

The temperature impact on L-asparaginase stability was studied and the maximum L-asparaginase stability was recorded at $40{ }^{\circ} \mathrm{C}$ (Fig. 8) with retained enzyme activity of $97.44 \%$ from initial activity after incubation time of $20 \mathrm{~min}$. However, enzyme exposure to higher temperature

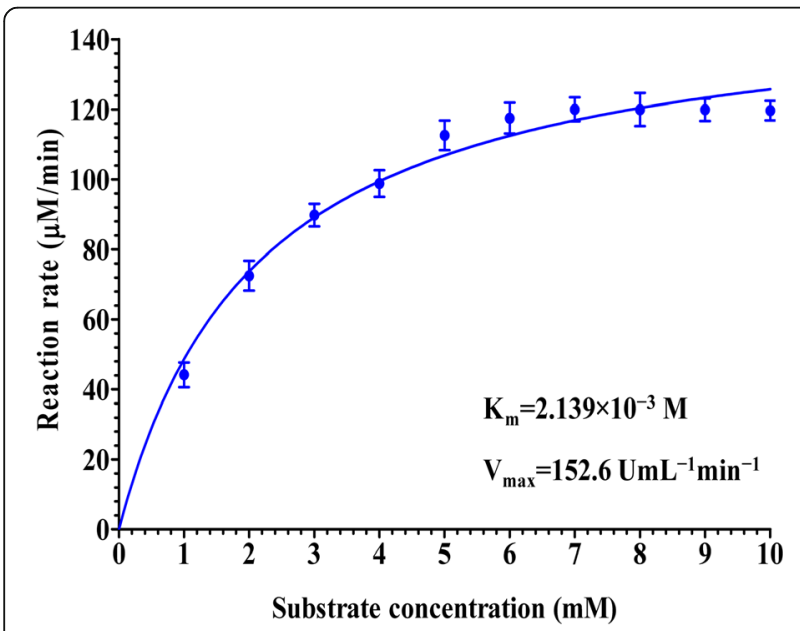

Fig. 7 Michaelis-Menten plot for L-asparaginase produced by Streptomyces brollosae NEAE-115 and longer incubation time of $50{ }^{\circ} \mathrm{C}$ and $80{ }^{\circ} \mathrm{C}$ for $90 \mathrm{~min}$ led to observed rapid decrease in L-asparaginase activity with residual activity of 31.84 and $7.69 \%$; respectively.

On the other hand, to reveal heat inactivation half-life time $\left(\mathrm{T}_{1 / 2}\right)$ of the enzyme at the used temperatures and heat deactivation constant $\left(\mathrm{k}_{\mathrm{d}}\right)$, the linear regression of the obtained results was performed using Graph-Pad Prism software by fitting the data points to first order equation according to Eqs. (4) and (5) and their values were listed in Table 2. The stability of L-asparaginase was expressed as a percentage of residual activity compared to the initial activity of the un-treated enzyme activity which considered as a control (100\%). The enzyme half life time $\left(\mathrm{T}_{1 / 2}\right)$ of $\mathrm{L}$-asparaginase was found to be $65.02 \mathrm{~min}$ at $50^{\circ} \mathrm{C}$ and $62.65 \mathrm{~min}$ at $60^{\circ} \mathrm{C}$. However, enzyme activity destruction was recorded at $80{ }^{\circ} \mathrm{C}$ with low half-life time (49.60 $\mathrm{min})$.

\section{pH stability}

The purified L-asparaginase was more stable in alkaline $\mathrm{pH}$ than the acidic one; it retains $92.81 \%$ activity at $\mathrm{pH} 8.5$ even after incubation for $6 \mathrm{~h}$ and $61.64 \%$ activity after $24 \mathrm{~h}$ (Fig. 9). Moreover, the enzyme retains about $84.22 \%$ of its activity after $6 \mathrm{~h}$ at the $\mathrm{pH} 9.5$. At $\mathrm{pH} 4.5$ the enzyme retained $64.80 \%$ activity after $6 \mathrm{~h}$ and the residual activity was $20.47 \%$ after $24 \mathrm{~h}$. Half life time values in hours $\left(\mathrm{T}_{1 / 2}\right)$ based on $\mathrm{pH}$ studies of L-asparaginase produced by Streptomyces brollosae NEAE-115 are represented in Table 3. The enzyme half life time of L-asparaginase was found to be $33.135 \mathrm{~h}$ at $\mathrm{pH} 8.5$ and $28.506 \mathrm{~h}$ at $\mathrm{pH}$ 9.5. However, enzyme activity destruction was recorded at $\mathrm{pH} 4.5$ with low half-life time (15.888 h).

\section{Effect of metal ions, inhibitors and surfactants on L- asparaginase activity}

The effect of various metal ions, inhibitors and surfactants on the enzyme activity is represented in Fig. 10. The purified L-asparaginase from Streptomyces brollosae NEAE-115 was not significantly affected by the presence of metal ions $\left(\mathrm{Na}^{+}, \mathrm{K}^{+}, \mathrm{Fe}^{2+}\right)$ and $\beta$-mercaptoethanol. It is evident from the Fig. 10 that the enzyme activity enhanced considerably in the presence of $\mathrm{Mg}^{2+}(111.81 \%)$ and was maximal in the presence of $\mathrm{Mn}^{2+}, \mathrm{Co}^{2+}$ and Tween 80 by $145.15,143.04$ and $121.52 \%$; respectively (acted as activators for L-asparaginase activity). However, a slight decrease, around 14.8 and $16 \%$, in L-asparaginase activity was observed in the presence of $\mathrm{Zn}^{2+}$ and $\mathrm{Ca}^{2+}$; respectively. Moreover, the presence of EDTA and urea acted as inhibitors of L-asparaginase activity reducing its activity by 37.55 and $57.8 \%$; respectively. The presence of $\mathrm{Ni}^{2+}, \mathrm{Hg}^{2+}, \mathrm{Ba}^{2+}$ and $\mathrm{Cu}^{2+}$ acted as a potent inhibitor, reducing about 74.68, 59.5, 56.4 and 49.8\%; respectively of the L-asparaginase activity. The presence of sodium azide 


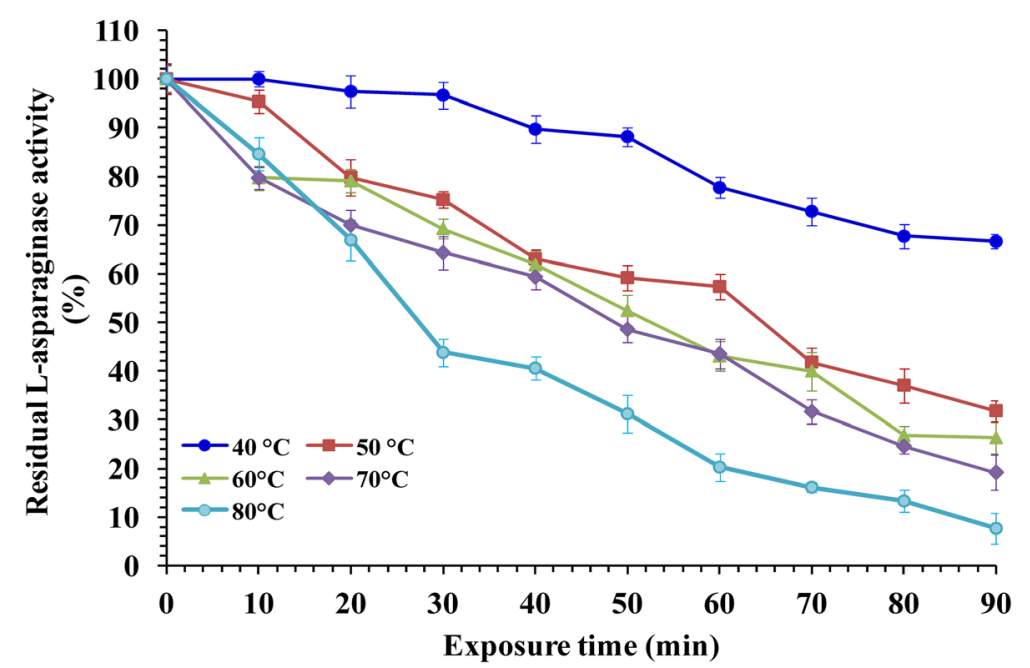

Fig. 8 Thermal stability of L-asparaginase as a function of the time of the reaction

also acted as an inhibitor, reducing about $45.15 \%$ of the L-asparaginase activity.

\section{Antitumor activity of purified L-asparaginase and immunogenicity assessment}

Treatment with commercial L-asparaginase significantly decreased the relative tumor size compared to the control group, showing 33\% tumor growth (i.e. 67\% tumor growth inhibition). While mice treated with Streptomyces brollosae NEAE-115 L-asparaginase showed 79\% tumor growth inhibition showing a significantly higher cytotoxic effect when compared to commercial L-asparaginase group (Table 4). One of the most important limitation of L-asparaginase as anticancer drug is that the allergic reactions exhibited by immune system of the patients receiving the medication of L-asparaginase. Characterization of the immunogenicity profile of L-asparaginase in mice and the levels of specific antibodies (IgG immunoglobulin) against L-asparaginase was measured in sera using ELISA method. Therapeutic efficacy and evaluation of anti-L-asparaginase IgG antibody concentrations in mice receiving Streptomyces brollosae NEAE-115 L-asparaginase preparations was carried out simultaneously with the commercial L-asparaginase in

Table 2 Half life time $\left(T_{1 / 2}\right)$ and heat deactivation constant $\left(k_{d}\right)$ of L-asparaginase produced by Streptomyces brollosae NEAE-115

\begin{tabular}{llll}
\hline Temperature $\left({ }^{\circ} \mathrm{C}\right)$ & Half life time $(\mathrm{min})$ & $\mathrm{k}_{\mathrm{d}}(\mathrm{min})$ & $R^{2}$ value \\
\hline 40 & 116.50 & 0.006 & 0.94 \\
50 & 65.02 & 0.011 & 0.98 \\
60 & 62.65 & 0.011 & 0.97 \\
70 & 59.91 & 0.012 & 0.97 \\
80 & 49.60 & 0.014 & 0.93 \\
\hline
\end{tabular}

order to evaluate the superiority of the new product. There was a gradual increase in L-asparaginase IgG titre in both commercial L-asparaginase or Streptomyces brollosae NEAE-115 L-asparaginase-inoculated mice (Fig. 11). However significant anti-asparaginase IgG titer was observed in commercial L-asparaginase group when compared to the other group of mice inoculated by Streptomyces brollosae NEAE-115 L-asparaginase due to the highly immunogenic nature of the commercial asparaginase. The results demonstrated that the immunogenicity of the Streptomyces brollosae NEAE-115 L-asparaginase was remarkably reduced.

\section{Discussion}

In the current study, L-asparaginase produced by Streptomyces brollosae NEAE-115 was detected by forming pink zone surrounding the colony. The pink zone resulted from the breakdown of amide bond in asparagine in the growth medium by L-asparaginase to aspartate and ammonia that changed the color of phenol red to pink [27].

The produced enzyme was partially purified by ammonium sulphate precipitation and pure enzyme was reached using ion-exchange chromatography. Recently L-asparaginase enzyme from strains Streptomyces noursei [28] and Streptomyces gulbergenesis [13] with an overall purification of 98.23 and 82.12 fold in final purification were carried out successfully. Sahu et al. [27] extracted the L-asparaginase from the actinomycete strain LA-29 isolated from the gut contents of the fish and the enzyme was purified 18-fold and from which $1.9 \%$ of protein was recovered and showed the specific activity of about $13.57 \mathrm{IU} / \mathrm{mg}$ of protein. Narayana et al. [29] and El-Bessoumy et al. [30] reported 99.3 and 106 fold 


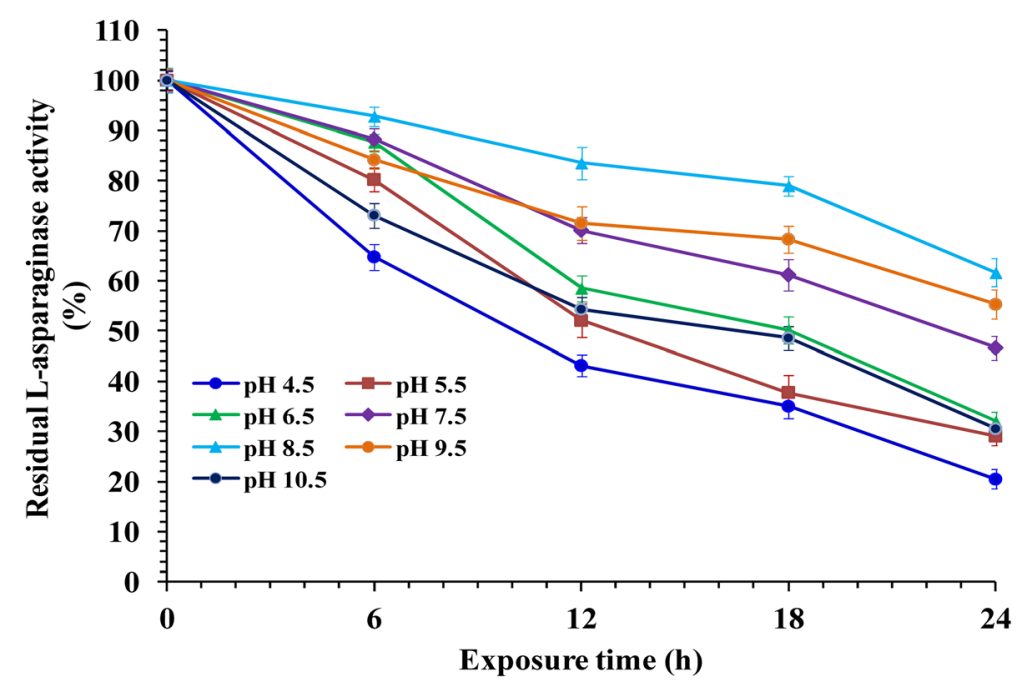

Fig. $9 \mathrm{pH}$ stability of $\mathrm{L}$-asparaginase at different times of the reaction

purification of L-asparaginase from Streptomyces albidoflavus and Pseudomonas aeroginosa 50,071; respectively, by CM Sephedex C-50 column chromatography.

SDS-PAGE separation revealed only one distinctive band of the enzyme preparation, no detectable contamination. L-asparaginase was therefore a homogenous protein. The molecular weight for the individual band is determined with a molecular mass of $67 \mathrm{kDa}$. The molecular weight of the L-asparaginase was found to be varied according to the source of enzyme. Purified L-asparaginase from Bacillus sp. [31], Streptomyces gulbargensis [13], Streptomyces albidoflavus [29], Streptomyces PDK2 [32], and Streptomyces noursei [28] exhibited a molecular weight of $45,85,112,140 \mathrm{kDa}$ and $102 \mathrm{kDa}$; respectively.

The amidases enzymes such as L-asparaginase are generally stable and active at neutral and alkaline $\mathrm{pH}$, whereas, earlier reporters showed optimum amidase activity at $\mathrm{pH}$ ranging from 5.0 to 9.0 [33]. The optimum $\mathrm{pH} 8.5$ was also reported for L-asparaginase purified from Streptomyces sp. PDK7 [32]. However, the optimal L-asparaginase activity from Streptomyces gulbargensis

Table 3 Half life time values in hours $\left(T_{1 / 2}\right)$ based on $\mathrm{pH}$ studies of L-asparaginase produced by Streptomyces brollosae NEAE-115

\begin{tabular}{llll}
\hline $\mathrm{pH}$ & $\mathrm{T}_{1 / 2}(\mathrm{~h})$ & $P$-value & $R^{2}$ value \\
\hline 4.5 & 15.888 & 0.0077 & 0.9321 \\
5.5 & 16.276 & 0.0029 & 0.9644 \\
6.5 & 17.289 & 0.0017 & 0.9748 \\
7.5 & 22.422 & 0.0003 & 0.9921 \\
8.5 & 33.135 & 0.0039 & 0.9563 \\
9.5 & 28.506 & 0.003 & 0.9634 \\
10.5 & 18.355 & 0.0039 & 0.9564 \\
\hline
\end{tabular}

was reported at pH 9.0 [13]. Narayana et al. [29] have reported the maximum L-asparaginase at $\mathrm{pH} 7.5$ by Streptomyces albidoflavus. Khamna et al. [34] have also reported maximum L-asparaginase activity at $\mathrm{pH} 7.0$ using Streptomyces sp.

The L-asparaginase activity of Streptomyces brollosae NEAE-115 was gradually increased with increasing incubation time up to $50 \mathrm{~min}$. However, longer time of incubation with substrate resulted in reduction of L-asparaginase activity which may due to the product inhibition. The purified L-asparaginase from Streptomyces noursei showed maximum activity at $35 \mathrm{~min}$ of incubation time [28]. In addition, L-asparaginase purified from Pseudomonas aeruginosa 50,071 reached its maximum activity at $30 \mathrm{~min}$ [30].

L-asparaginase was active over a wide range of temperature from 25 to $60{ }^{\circ} \mathrm{C}$ with an optimum L-asparaginase activity of $87.81 \mathrm{U} / \mathrm{mL}$ at $\mathrm{pH} 37^{\circ} \mathrm{C}$ and lower L-asparaginase activities observed at higher temperatures. Similarly, Siddalingeshwara and Lingappa [35] recorded optimum temperature $37^{\circ} \mathrm{C}$ for maximum enzyme activity from Aspergillus terreus KLS2. This property of enzyme makes it most suitable for complete elimination of asparagine from the body when tumor patient treated with L-asparaginase. Comparable results were reported for the maximum activity of purified L-asparaginase from Streptomyces gulbargensis at $40{ }^{\circ} \mathrm{C}$ [13].

Michaelis-Menten plot gave a $K_{m}$ value of $2.139 \times$ $10^{-3} \mathrm{M}$ with L-asparagine as substrate and $\mathrm{V}_{\max }$ of 152.6 $\mathrm{UmL}^{-1} \mathrm{~min}^{-1}$ for the hydrolysis of L-asparagine by L-asparaginase from Streptomyces brollosae NEAE-115 and $\mathrm{K}_{\mathrm{m}}$ value of $1.76 \times 10^{-4} \mathrm{M}$ and $\mathrm{V}_{\max }$ of $121.7 \mathrm{UmL}^{-1} \mathrm{~min}^{-1}$ for the hydrolysis of $\mathrm{L}$-asparagine by commercially available L-asparaginase from E. coli (Sigma-Aldrich, 


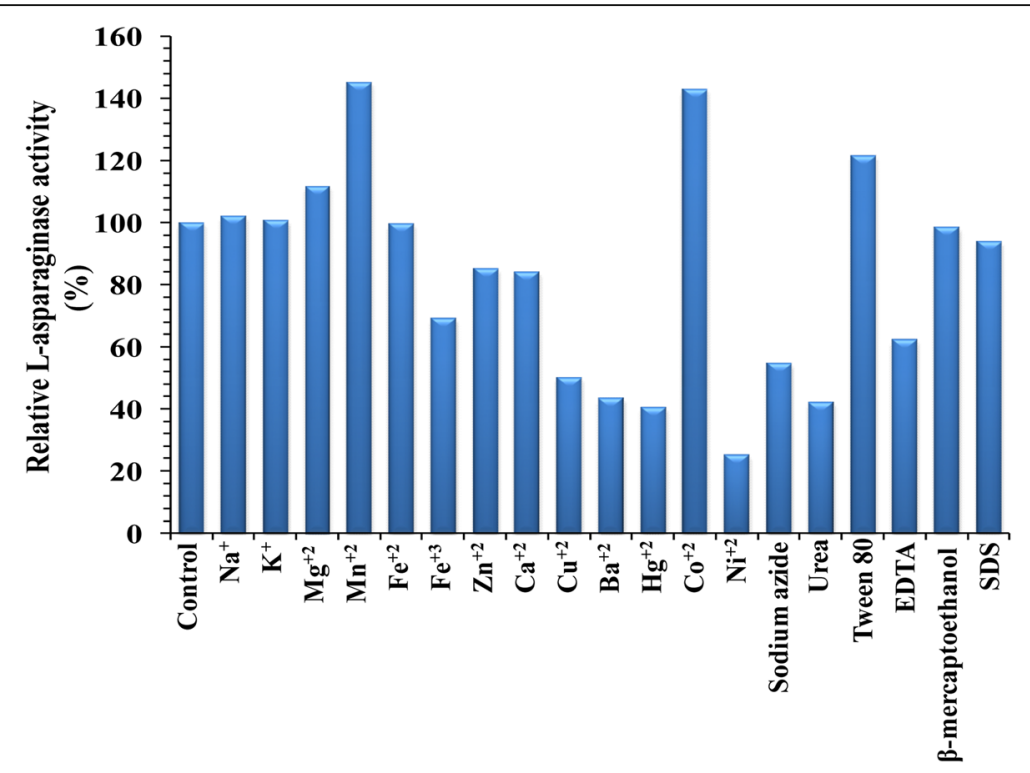

Fig. 10 Effect of metal ions, inhibitors and surfactants on L-asparaginase activity

Product Number: A3809; CAS Number: 9015-68-3). Senthil Kumar and Selvam [36] have reported the apparent $\mathrm{K}_{\mathrm{m}}$ and $\mathrm{V}_{\max }$ of $5.98 \times 10^{-2} \mathrm{M}$ and $3.547 \mathrm{IU} / \mu \mathrm{g}$; respectively in Streptomyces radiopugnans MS. Table 5 summerize the biochemical properties of some microbial L-asparaginases [13, 21, 22, 29, 30, 36-48].

L-asparaginase of different microbial sources has different $K_{m}$ value which defined as the half maximal velocity of the enzymatic reaction as a function of substrate concentrations and stating the filling of half of the enzyme active sites in the tested sample in the steady state. Therefore, $K_{m}$ values illustrate the affinity of the enzyme for its substrate [49]. In consequence, lower and higher $\mathrm{K}_{\mathrm{m}}$ values mean stronger binding ability and lower enzyme affinity to its substrate; respectively. However, the kinetic constants of the enzymes in terms of $\mathrm{K}_{\mathrm{m}}$ and $\mathrm{V}_{\text {max }}$ can be affected by many factors, including, enzyme type, enzyme different forms (crude, modified or purified), enzyme source, used conditions (temperature, $\mathrm{pH}$, etc.), substrate type and the used procedure of assay [50]. The rate of an enzyme-catalyzed reaction increases with the increasing of the substrate concentration beyond a certain level called maximal velocity rate $\left(\mathrm{V}_{\max }\right)$; at $\mathrm{V}_{\max }$ increase in substrate concentration does not cause any increase in reaction rate as there is no more enzyme available for reacting with substrate. The maximal rate, $V_{\max }$, reveals the number of substrate molecules converted into product by the enzyme per unit of time when the catalytic sites on the enzyme are fully saturated with its substrate [51].

According to the data reported under this investigation, the maximum thermal stability behavior of $\mathrm{L}$-asparaginase was at $40{ }^{\circ} \mathrm{C}$. An earlier study demonstrated by Senthil Kumar and Selvam [36], the pre incubation at $40{ }^{\circ} \mathrm{C}$ for $60 \mathrm{~min}$ of the purified L-asparaginase from Streptomyces radiopugnans MS1 resulted in no significant loss of enzyme activity. Similar results were recorded with many other microorganisms such as Streptomyces noursei [28], Pseudomonas stutzeri MB 405 [38] and E. carotovora [52]. "Enzyme stability and thermal deactivation are considered the major constraints in rapid development of biotechnology process. In addition, it considered a very important tool used in enzyme selection for industrial uses".

The purified L-asparaginase was more stable in alkaline $\mathrm{pH}$ and similar findings were reported for $\mathrm{L}$-asparaginase

Table 4 Effect of L-asparaginase on tumor size in mice after treatment

\begin{tabular}{|c|c|c|c|c|}
\hline \multirow[t]{2}{*}{ Treatment } & \multicolumn{4}{|c|}{ Tumor size $\left(\mathrm{mm}^{3}\right)$} \\
\hline & Day 0 & Day 14 & $\Delta \mathrm{T} / \Delta \mathrm{C}(\%)$ & $\%$ Inhibition \\
\hline Control & $69.0 \pm 2.2$ & $585.0 \pm 40.8$ & 100 & 0 \\
\hline Commercial L-asparaginase & $67.0 \pm 4.5$ & $240.7 \pm 9.4^{*}$ & 33 & 67 \\
\hline Streptomyces brollosae NEAE-115 L-asparaginase & $77.6 \pm 3.7$ & $188.3 \pm 8.33 \$$ & 21 & 79 \\
\hline
\end{tabular}

Data are expressed as mean \pm SEM, $n=6$

* Significantly different from control group using One-Way ANOVA followed by Tukey-Kramer multiple comparisons test $(P<0.05)$. $\$$ Significantly different from commercial L-asparaginase-treated group using One-Way ANOVA followed by Tukey-Kramer multiple comparisons test $(P<0.05)$. Mann-Whitney $U$ test, $* P<0.05$ 


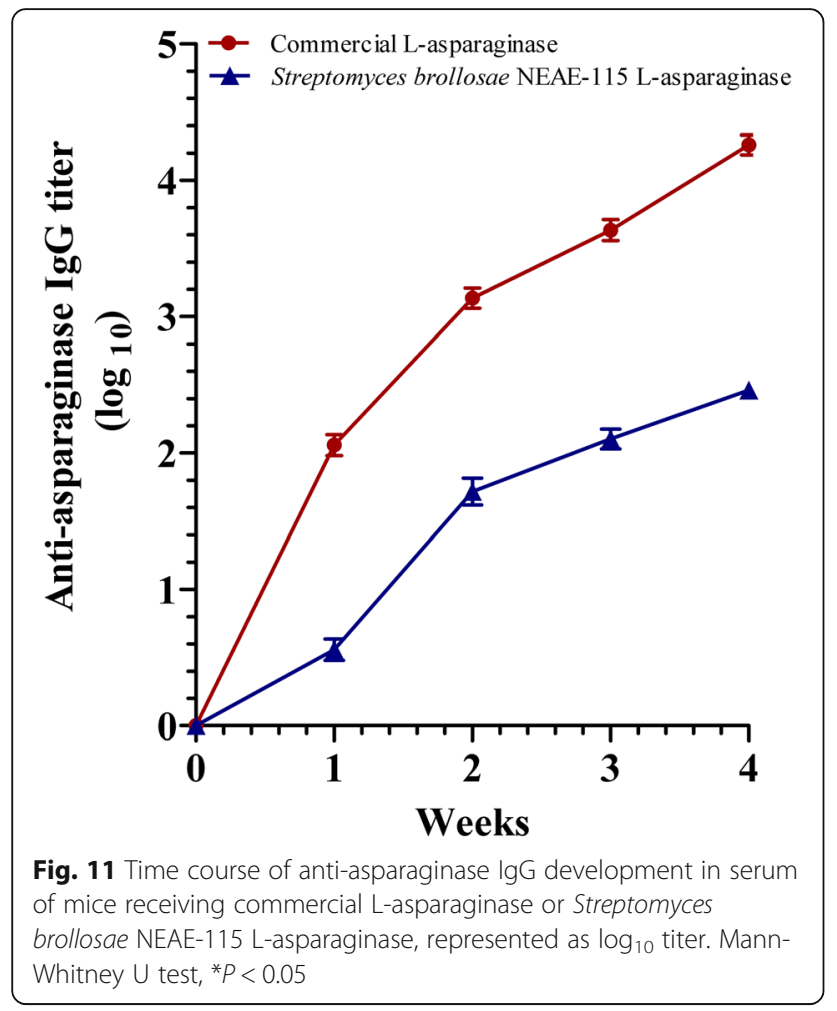

extracted from Pseudomonas stutzeri MB-405 which is maximally stable at $\mathrm{pH}$ range from 7.5 to 9.5 [38] .

Among the different metal ions tested $\mathrm{Mn}^{2+}$ enhanced the L-asparaginase activity by $18 \%$ as reported by earlier workers on Fusarium culmorum ASP-87 and Mucor hiemalis [22, 53]. Husain et al. [37] reported that the monovalent cations such as $\mathrm{Na}^{+}$and $\mathrm{K}^{+}$enhanced the activity of Enterobacter cloacae L-asparaginase. $\mathrm{K}^{+}$acted also as enhancer on Pectobacterium carotovorum asparaginase [54]. Radha et al. [21] reported that the activity of Vibrio cholerae $\mathrm{L}$-asparaginase was enhanced in presence of $\mathrm{Ca}^{2+}$ to $130 \%$. Also, Meghavarnam and Janakiraman [22] reported that the non ionic surfactant tween 80 was found to enhance the activity of the enzyme by $16 \%$. Senthil Kumar and Selvam [36] reported that the EDTA acts as an inducer in Streptomyces radiopugnans MS1. EDTA as metal chelator agent had no effect on $P$. carotovorum asparaginase [54]. However, L-asparaginase was completely inhibited by EDTA as reported by Borkotaky and Bezbaruah [55]. Whereas, EDTA inhibited the activity of fungal $\mathrm{L}$-asparaginase from Trichoderma viride by $88 \%$ [56]. Also, the L-asparaginase activity of Fusarium Culmorum ASP-87 was inhibited by EDTA, SDS and $\mathrm{Cu}^{2+}$ [22]. Husain et al. [37] reported that the divalent and trivalent cations, $\mathrm{Ca}^{2+}, \mathrm{Mg}^{2+}, \mathrm{Zn}^{2+}, \mathrm{Mn}^{2+}$, and $\mathrm{Fe}^{3+}$ inhibited the enzyme activity. Radha et al. [21] reported that the activity of Vibrio cholerae L-asparaginase was inhibited by divalent cations $\mathrm{Ni}^{2+}, \mathrm{Mg}^{2+}, \mathrm{Fe}^{2+}, \mathrm{Mn}^{2+}, \mathrm{Zn}^{2+}$ and the complete loss in the activity was perceived in the presence $\mathrm{Cu}^{2+}$. Whereas, Archana and Raja [57] reported that $\mathrm{Cu}^{2+}$ inhibited the activity of L-asparaginase produced by $A s$ pergillus nidulans by $84 \%$. Kumar et al. [54] reported that $\mathrm{Hg}^{2+}$ inhibited the L-asparaginase activity produced by Pectobacterium carotovorum by $80 \%$. However, L-asparaginase was completely inhibited by $\mathrm{Fe}^{2+}$ and $\mathrm{Ni}^{2+}$ [58] and $\mathrm{Cu}^{2+}$ and $\mathrm{Zn}^{2+}$ [59]. While, Husain et al. [37]

Table 5 Biochemical properties of some microbial L-asparaginases

\begin{tabular}{|c|c|c|c|c|c|c|c|}
\hline Microbial source & pH optima & $\begin{array}{l}\text { Temperature } \\
\text { optima }\left({ }^{\circ} \mathrm{C}\right)\end{array}$ & $K_{m}(M)$ & $V_{\max }$ & $\begin{array}{l}\text { Specific activity } \\
\text { (U/mg protein) }\end{array}$ & $\begin{array}{l}\text { Molecular } \\
\text { weight (kDa) }\end{array}$ & References \\
\hline Streptomyces albidoflavus & 7.5 & 35 & - & - & 437 & 112 & [29] \\
\hline Streptomyces gulbargensis & 9 & 40 & - & - & 2053 & 85 & [13] \\
\hline Streptomyces radiopugnans MS & 6 & 40 & $5.98 \times 10^{-2}$ & $3.547 \mathrm{IU} / \mu \mathrm{g}$ & 5035.28 & 133.25 & [36] \\
\hline Enterobacter cloacae & $7-8$ & $35-40$ & $1.58 \times 10^{-3}$ & $2.22 \mathrm{IU} / \mu \mathrm{g}$ & 105.07 & 52 & [37] \\
\hline Pseudomonas aeruginosa & 9 & 37 & $0.147 \times 10^{-3}$ & $35.7 \mathrm{IU}$ & 1900 & 160 & {$[30]$} \\
\hline Vibrio cholerae & 7 & 37 & $1.1 \times 10^{-3}$ & $1006 \mu \mathrm{M} / \mathrm{min}$ & 648.9 & 132 & [21] \\
\hline Pseudomonas stutzeri & 9 & 37 & $1.45 \times 10^{-4}$ & - & 732.3 & 34 & [38] \\
\hline Pseudomonas fluorescens & $8-9$ & & $4.1 \times 10^{-4}$ & - & 500 & 70 & [39] \\
\hline Azotobacter vinelandii & 8.6 & 48 & $1.1 \times 10^{-4}$ & & 2.47 & 84 & {$[40]$} \\
\hline E. coli & $7-8$ & 37 & $3.5 \times 10^{-3}$ & - & $150-250$ & 139 & {$[41-43]$} \\
\hline Erwinia aroideae & 8.2 & 45 & $2.8 \times 10^{-3}$ & - & - & 155 & [44] \\
\hline Corynebacterium glutamicum & 7 & 40 & $2.5 \times 10^{-3}$ & - & 2020 & 80 & [45] \\
\hline Bacillus coagulans & $8.8-9.7$ & 55 & $5 \times 10^{-3}$ & $5.83 \times 10^{-5} \mathrm{M} / \mathrm{h}$ & 10.9 & 84 & [46] \\
\hline Bacillus licheniformis & $6-10$ & 40 & $1.4 \times 10^{-5}$ & $4.03 \mathrm{IU}$ & 697.09 & 134.8 & [47] \\
\hline Aspergillus oryzae CCT 3940 & 8 & 50 & $0.66 \times 10^{-3}$ & $313 \mathrm{IU} / \mathrm{mL}$ & 91 & 115 & [48] \\
\hline Fusarium culmorum ASP-87 & 8 & 45 & $3.57 \times 10^{-3}$ & $0.5 \mu \mathrm{mol} / \mathrm{mL} / \mathrm{min}$ & 16.66 & 90 & [22] \\
\hline
\end{tabular}


reported that the asparaginase activity did not detected when enzyme was incubated with metal ions viz. $\mathrm{Cd}^{2+}$, $\mathrm{Ni}^{2+}$ and $\mathrm{Hg}^{2+}$. Other metal ions like $\mathrm{Ca}^{2+}$ and $\mathrm{Mg}^{2+}$ did not have much effect on enzyme activity [22] and $\beta$-mercaptoethanol did not have any effect on fungal L-asparaginase activity from Trichoderma viride [56].

$\mathrm{Mn}^{2+}, \mathrm{Co}^{2+}$ and $\mathrm{Mg}^{2+}$ ions increase the enzyme activity suggests that these metals ions can serve as co-factors, which can help to activate the enzymatic reaction. $\mathrm{Mg}^{2+}$ was thought to be the activating metal; $\mathrm{Mg}^{2+}$ may activate the substrate, bound directly to the enzyme-substrate complex. $\mathrm{Mg}^{2+}$ locks the enzyme-substrate complex in place and then rapidly causes release of the reaction products [60]. This corresponds to fast dissociation rates for the enzyme-product complex rendering more favorable substrate binding sites. Metal ions play a crucial role in maintaining the active configuration of the enzymes at elevated temperatures by protecting them against thermal denaturation [61]. It was reported that the divalent cations $\mathrm{Mn}^{2+}$ and $\mathrm{Mg}^{2+}$ increased the thermal stability of Bacillus alkaline proteases [62]. Whereas, the monovalent cations, $\mathrm{Na}^{+}$were found to enhanced asparaginase activity, indicates that the enzyme might contain $\mathrm{Na}^{+}$ions [37]. Thakur et al. [53] found that $\mathrm{Mn}^{2+}$ enhanced L-asparaginase activity and concluded that L-asparaginase is in general a metal-activated enzyme. Tween 80 was found to enhance the activity of the enzyme by $21.52 \%$. Surfactants appear to increase quick and direct contact of enzymes with substrate sites [63]. McAllister et al. [64] reported that Tween 80 increased the stability and substrate binding capacity of enzymes under in vitro conditions.

One of the most important limitation of L-asparaginase as anticancer drug is that the allergic reactions exhibited by immune system of the patients receiving the medication of $\mathrm{L}$-asparaginase. The patient immune system reacts in many different ways against the drug such as, the development of high titers of serum IgG antibodies which in the majority of cases interfere with the therapeutic effect of the enzyme [65]. Drug's immunogenicity is fundamental obstacle which limits the therapy with foreign proteins in humans. A real immunological tolerance that would require antigen specific $\mathrm{T}$-cell mediated immunosuppression is difficult to achieve. One way to overcome this problem for a limited time is to switch to another preparation [66].

\section{Conclusions}

This study is clearly revealed that soils can be considered as a rich source of L-asparaginase producing actinomycetes. Streptomyces brollosae NEAE-115 isolated from Egypt soil has the ability to produce a significant amount of L-asparaginase. A pure and efficient enzyme activity of L-asparaginase could be obtained using only two purification steps. The excellent characteristics of this enzyme like high catalytic activity over a wide range of temperature and $\mathrm{pH}$, high substrate specificity, maximum activity at body temperature and its considerable thermal and $\mathrm{pH}$ stabilities, makes it highly valuable to be exploited as a potent anticancer agent. Furthermore, mice treated with Streptomyces brollosae NEAE-115 L-asparaginase showed $79 \%$ tumor growth inhibition with higher cytotoxic effect when compared to commercial L-asparaginase group. The current investigation concluded the isolated Streptomyces brollosae NEAE-115 used in this study could be a valuable potential source for $\mathrm{L}$-asparaginase.

\section{Abbreviations}

ELISA: Enzyme-linked immunosorbent assay; IgG: Immunoglobulin G; KDa: kilodalton; $\mathrm{K}_{\mathrm{m}}$ : Michaelis-Menten constant; SDS-PAGE: Sodium dodecyl sulfate-polyacrylamide gel electrophoresis; $T_{1 / 2}:$ Half-life time; $V_{\text {max }}$ : Maximal velocity

\section{Acknowledgments}

The authors gratefully acknowledge the Science and Technology Development Fund (STDF), Egypt, for their financial support of this paper which is a part of the Grant No. 4943.

Funding

The Science and Technology Development Fund (STDF), Egypt.

\section{Availability of data and materials}

The datasets used and/or analyzed during the current study are available from the corresponding author on reasonable requests.

\section{Authors' contributions}

NEE proposed the research concept, designed the experiments, providing necessary tools for experiments, experimental instructions, conducted most of the experiments, analyzed and interpreted the data, wrote the manuscript and final approval of the manuscript. SFD contributed in the purification step using DEAE Sepharose CL-6B column, contributed to revision of this part of the manuscript. SME performed the experiments and contributed substantially to acquisition of data and drafting the manuscript. GMS contributed substantially to conception and design, acquisition, analysis and interpretation of data, conducted and wrote the part of antitumor activity and immunogenicity assessment. All authors agreed to be accountable for all aspects of the work in ensuring that questions related to the accuracy or integrity of any part of the work are appropriately investigated and resolved. All authors read and approved the manuscript to be published.

\section{Ethics approval and consent to participate}

The in vivo experimental protocol in this study was approved by the Research Ethics Committee, Faculty of pharmacy, Mansoura University, Mansoura, Egypt. All the experiments were performed in accordance with the relevant guidelines and regulations.

\section{Consent for publication}

Not applicable.

\section{Competing interests}

The authors declare that they have no competing interests.

\section{Publisher's Note}

Springer Nature remains neutral with regard to jurisdictional claims in published maps and institutional affiliations.

\section{Author details}

${ }^{1}$ Department of Bioprocess Development, Genetic Engineering and Biotechnology Research Institute, City of Scientific Research and Technological Applications, Alexandria, Egypt. ${ }^{2}$ Department of Protein Research Genetic Engineering and Biotechnology Research Institute, City of Scientific Research and Technological Applications, Alexandria, Egypt. ${ }^{3}$ Department of Pharmacology and Toxicology, Faculty of Pharmacy, Mansoura University, Mansoura, Egypt. 


\section{Received: 27 October 2017 Accepted: 9 August 2018}

\section{Published online: 23 August 2018}

\section{References}

1. Savitri AN, Azmi W. Microbial L-asparaginase: A potent antitumour enzyme. Indian J Biotechnol. 2003;2:184-94.

2. Narta UK, Kanwar SS, Azmi W. Pharmacological and clinical evaluation of $\mathrm{L}$ aspaprginase in the treatment of leukemia. Crit Rev Oncol Hematol. 2007;61: 208-21

3. Duval M, Suciu S, Ferster A, Rialland X, Nelken B, Lutz P, Benoit Y, Robert A, Manel AM, Vilmer E. Comparison of Escherichia coli-asparaginase with Erwinia-asparaginase in the treatment of childhood lymphoid malignancies: results of a randomized European Organisation for Research and Treatment of Cancer-Children's leukemia group phase 3 trial. Blood. 2002;99:2734-9.

4. Ambi Rani S, Sundaram L, Vasantha P.B. A study on in vitro antioxidant and anticancer activity of L-asparaginase. J Pharm Res. 2011;5:1463-66.

5. El-Naggar NE, El-Ewasy SM, El-Shweihy NM. Microbial L-asparaginase as a potential therapeutic agent for the treatment of acute lymphoblastic leukemia: the pros and cons. Int J Pharmacol. 2014;10:182-99.

6. Verma N, Kumar K, Kaur G, Anand S. E. coli K-12 asparaginase-based asparagine biosensor for leukemia. Artif Cells Blood Substit Immobil Biotechnol. 2007;35:449-56.

7. Kotzia GA, Labrou NE. Cloning, expression and characterisation of Erwinia carotovora L-asparaginase. J Biotechnol. 2005;119:309-23.

8. Ohnuma T, Holland JF, Freeman A, Sinks LF. Biochemical and pharmacological studies with L-asparaginase in man. Cancer Res. 1970;30:2297-305.

9. El-Naggar NE, Diras SF, Soliman HM, El-Deeb NM, El-Ewasy SM. Purification, characterization, cytotoxicity and anticancer activities of L-asparaginase, anti-colon cancer protein, from the newly isolated alkaliphilic Streptomyces fradiae NEAE-82. Sci Rep. 2016;6:32926.

10. Manivasagan P, Venkatesan J, Sivakumar K, Kim SK. Marine actinobacterial metabolites: current status and future perspectives. Microbiol Res. 2013;168:311-32.

11. El-Naggar NE. Extracellular production of the oncolytic enzyme, Lasparaginase, by newly isolated Streptomyces sp. strain NEAE-95 as potential microbial cell factories: Optimization of culture conditions using response surface methodology. Curr Pharm Biotechnol. 2015;16:162-78.

12. El-Naggar NE, Moawad H, El-Shweihy NM, El-Ewasy SM. Optimization of culture conditions for production of the anti-leukemic glutaminase free Lasparaginase by newly isolated Streptomyces olivaceus NEAE-119 using response surface methodology. Biomed Res Int. 2015;627031. https://doi. org/10.1155/2015/627031.

13. Amena S, Vishalakshi N, Prabhakar M, Dayanand A, Lingappa K. Production, purification and characterization of L-asparaginase from Streptomyces gulbargensis. Brazil J Microbiol. 2010;41:173-8.

14. De Jong PJ. L-asparaginase production by Streptomyces griseus. Appl Microbial. 1972:23:1163-4.

15. Saxena RK, Sinha U. L-asparaginase and glutaminase activities in culture filtrates of Aspergillus nidulans. Curr Sci. 1981;50:218-9.

16. Gulati R, Saxena R, Gupta R. A rapid plate assay for screening L-asparaginase producing microorganisms. Lett Appl Microbiol. 1997;24:23-6.

17. Wriston J, Yellin T. L-asparaginase: a review. Adv Enzymol Relat Areas Mol Biol. 1973;39:185-248.

18. Imada A, Igarasi S, Nakahama K. Isona. M. Asparaginase and glutaminase activities of microorganisms. J Gen Microbiol. 1973;76:85-99.

19. Lowry OH, Rosebrough NJ, Farr AL, Randall RJ. Protein measurement with the Folin phenol reagent. J Biol Chem. 1951;193:265-75.

20. Sadana A. Biocatalysis: fundamentals of enzyme Deactvation kinetics. Englewood Cliffs: Prentice-Hall, Inc.; 1995.

21. Radha R, Arumugam N, Gummadi SN. Glutaminase free L-asparaginase from Vibrio cholerae: heterologous expression, purification and biochemical characterization. Int J Biol Macromol. 2018:4(111):129-38.

22. Meghavarnam AK, Janakiraman S. Purification and characterization of therapeutic enzyme L-asparaginase from a tropical soil fungal isolate Fusarium culmorum ASP-87. MOJ Proteomics Bioinform. 2015;2(6):1-6.

23. Laemmli UK. Cleavage of structural proteins during the assembly of the head of bacteriophage T4. Nature. 1970;227:680-5.

24. Gothoskar SV, Ranadive KJ. Anticancer screening of SAN-AB: an extract of marking nut, semecarpus anacardium. Indian J Exp Biol. 1971;9:372-5.

25. Raja Naresh RA, Ndupa N, Uma DP. Effect of macrophage activation on niosome encapsulated bleomycin in tumor-bearing mice. Ind J Pharamcol. 1996;28:175-80.
26. Schirner M, Hoffmann J, Menrad A, Schneider MR. Antiangiogenic chemotherapeutic agents: characterization in comparison to their tumor growth inhibition in human renal cell carcinoma models. Clin Cancer Res. 1998:4:1331-6.

27. Sahu MK, Poorani E, Sivakumar K, Thangaradjou T, Kannan L. Partial purification and anti-leukemic activity of L-asparaginase enzyme of the actinomycete strain LA-29 isolated from the estuarine fish. Mugil cephalus (Linn). J Environ Biol. 2007;28:645-50.

28. Dharmaraj S. Study of L-asparaginase production by Streptomyces noursei MTCC 10469, isolated from marine sponge Callyspongia diffusa. Iran J Biotechnol. 2011:9:102-8.

29. Narayana K, Kumar K, Vijayalakshmi M. L-asparaginase production by Streptomyces albidoflavus. Indian J Microbiol. 2008:48:331-6.

30. El-Bessoumy AA, Sarhan M, Mansour J. Production, isolation, and purification of L-asparaginase from Pseudomonas aeruginosa 50071 using solid-state fermentation. J Biochem Mol Biol. 2004;37:387-93.

31. Moorthy V, Ramalingam A, Sumantha A, Shankaranaya RT. Production, purification and characterisation of extracellular L-asparaginase from a soil isolate of Bacillus sp. Af J Microbiol Res. 2010:4:1862-7.

32. Dhevagi $P$, Poorani E. Isolation of L-asparaginase producing actinomycetes from marine sediments. Int J Curr Res Aca Rev. 2016;4:88-97.

33. Ohshima M, Yamamoto T, Soda K. Further characterization of glutaminase isozymes from Pseudomonas aeruginosa. Agri Biol Chem. 1976;40:2251-6.

34. Khamna S, Yokota A, Lumyong S. L-asparaginase production by actinomycetes isolated from some Thai medicinal plant rhizosphere soils. Int J Integ Biol. 2009;6:1-22

35. Siddalingeshwara KG, Lingappa K. Production and characterization of Lasparaginase- a tumour inhibitor. Int J Pharm Tech Res. 2011:3:314-9.

36. Senthil Kumar M, Selvam K. Isolation and purification of high efficiency Lasparaginase by quantitative preparative continuous elution SDS PAGE electrophoresis. J Microbial Biochem Technol. 2011;3:073-83.

37. Husain I, Sharma A, Kumar S, Malik F. Purification and characterization of glutaminase free asparaginase from Enterobacter cloacae: In-Vitro evaluation of cytotoxic potential against human myeloid leukemia HL-60 cells. PLoS One. 2016;11(2):e0148877.

38. Manna S, Sinha A, Sadhukhan R, Chakrabarty S. Purification, characterization and antitumor activity of L-asparaginase isolated from Pseudomonas stutzeri MB-405. Curr Microbiol. 1995:30:291-8.

39. Nilolaev Al, Sokolov NN, Kozlov EA, Kutsman ME. Isolation and properties of a homogeneous L-asparaginase preparation from Pseudomonas fluorescens AG. Biokhimiia. 1975:40:984-9.

40. Gaffar SA, Shethna YI. Purification and some biological properties of asparaginase from Azotobacter vinelandii. Appl Environ Microbiol. 1977:33:508-14.

41. Cedar H, Schwartz JH. Localization of the two L-asparaginases in anaerobically grown Escherichia coli. J Biol Chem. 1967;242:3753-4.

42. Whelan BA, Wriston JC. Purification and properties of asparaginase from Escherichia coli B. Biochemist. 1969:8:2386-93.

43. Willis RC, Woolfolk CA. Asparagine utilization in Escherichia coli. J Bacteriol. 1974;118:231-41.

44. Tiwari N, Dua RD. Purification and preliminary characterization of L-asparaginase from Enwinia aroideae NRRL B-138. Indian J Biochem Biophys. 1996;33:371-6.

45. Mesas JM, Gil JA, Martín JF. Characterization and partial purification of Lasparaginase from Corynebacterium glutamicum. J Gen Microbiol. 1990;136:515-9.

46. Law AS, Wriston JC Jr. Purification and properties of Bacillus coagulans Lasparaginase. Arch Biochem Biophys. 1971:147:744-52.

47. Mahajan RV, Kumar V, Rajendran V, Saran S, Ghosh PC, Saxena RK. Purification and characterization of a novel and robust L-asparaginase having low-glutaminase activity from Bacillus licheniformis: In vitro evaluation of anti-cancerous properties. PLoS One. 2014;9(6):e99037.

48. Dias FFG, Ruiz ALTG, Della Torre A, Sato HH. Purification, characterization and anti-proliferative activity of L-asparaginase from Aspergillus oryzae CCT 3940 with no glutaminase activity. Asian Pac J Trop Biomed. 2016;6:785-94.

49. Wulff G. Enzyme-like catalysis by molecularly imprinted polymers. Chem Reviews. 2002:102:1-28.

50. Copeland RA. Enzymes, A practical introduction to structure, mechanism and data analysis. 2nd ed. New York: Wiley-VCH; 2000.

51. Bisswanger H.. Enzyme kinetics. Principles and Methods. 2nd ed. Wiley-VCH Verlag GmbH \& Co.: Weinheim;2008.

52. Maladkar NK, Singh VK, Naik SR. Fermentative production and isolation of Lasparaginase from Erwinia carotovora, EC-113. Hindustan Antibiot Bull. 1992; 35:77-86. 
53. Thakur M, Lincoln L, Niyonzima FN, Sunil S. Isolation, purification and characterization of fungal extracellular L-asapraginase from Mucor hiemalis. J Biocat Biotrans. 2013;2:1-9.

54. Kumar S, Venkata Dasu V, Pakshirajan K. Purification and characterization of glutaminase-free L-asparaginase from Pectobacterium carotovorum MTCC 1428. Bioresour Technol. 2011;102(2):2077-82.

55. Borkotaky B, Bezbaruah R. Production and properties of asparaginase from a new Erwinia sp. Folia Microbiol. 2002;47:473-6.

56. Lincoln L, Francois N, Niyonzima Sunil SM. Purification and properties of a fungal L-asparaginase from Trichoderma viride pers: SF GREY. J Microbiol Biotechnol Food Sci. 2015:4(4):310-6.

57. Archana Rani J, Raja RP. Production, purification and characterization of Lasparaginase from Aspergillus nidulans by solid substrate fermentation. Eur J Biotechnol Bio. 2014;2(4):51-8.

58. Raha SK, Roy SK, Dey SK, Chakrabarty SL. Purification and properties of an Lasparaginase from Cylindrocarpon obtusisporum MB-10. J Biochem Int. 1990; 21:987-1000

59. Selvakumar N, Vanajakumar and Natarajan R. Partial purification, characterization and antitumor properties of $\mathrm{L}$-asparaginase (antileukemic agent) from a marine Vibrio. Bioactive compounds from marine organisms, Indo-US symposium 1989, edited by Thompson MF, Sarojini R and Nagabhushanam R. 1991;289-300.

60. Knape MJ, Ahuja GL, Bertinetti D, Burghardt NCG, Zimmermann B, Taylor SS, Herberg FW. Divalent metal ions $\mathrm{Mg}^{2+}$ and $\mathrm{Ca}^{2+}$ have distinct effects on protein kinase a activity and regulation. ACS Chem Biol. 2015;10(10):2303-15.

61. Kumar CG, Takagi H. Microbial alkaline proteases: from a bioindustrial viewpoint. Biotechnol Adv. 1999;17:561-94.

62. Moradian F, Khajeh K, Naderi-Manesh H, Sadeghizadeh M. Isolation, purification and characterization of a surfactants, laundry detergents and organic solvents-resistant alkaline protease from Bacillus sp. HR-08. Appl Biochem Biotechnol. 2009;159:33-45.

63. Castanon M, Wilke CR. Effect of the surfactant tween 80 on enzymatic hydrolysis of newspaper. Biotechno Bioengi Techno. 1981;23:1365-72.

64. McAllister TA, Stanford K, Bae HD, Treacher R, Hristov AN, Baah J, Shelford $J A$, Cheng KJ. Effect of a surfactant and exogenous enzymes on digestibility of feed and on growth performance and carcass traits of lambs. Canadian J Anim Sci. 2000:80:35-44.

65. Usman A. Seeking efficacy in L-asparaginase to combat acute lymphoblastic leukemia (ALL): a review. Afr J Pharm Pharm. 2015:9:793-805.

66. Neeta Asthana S, Azmi W. Microbial L-asparginase: A potent antitumor enzyme. Indian J Biotechnol. 2003;2:184-94.

Ready to submit your research? Choose BMC and benefit from:

- fast, convenient online submission

- thorough peer review by experienced researchers in your field

- rapid publication on acceptance

- support for research data, including large and complex data types

- gold Open Access which fosters wider collaboration and increased citations

- maximum visibility for your research: over $100 \mathrm{M}$ website views per year

At BMC, research is always in progress.

Learn more biomedcentral.com/submissions 